\title{
A Comparative Study of the Refinancing Announcement Effect of Listing Corporation in China
}

\author{
Wan Xiao, Yukun Zhang \\ School of Business Administration, South China University of Technology, Guangzhou, China \\ Email: 467464925@qq.com
}

How to cite this paper: Xiao, W. and Zhang, Y.K. (2018) A Comparative Study of the Refinancing Announcement Effect of Listing Corporation in China. American Journal of Industrial and Business Management, 8, 1757-1769.

https://doi.org/10.4236/ajibm.2018.88118

Received: July 16, 2018

Accepted: August 10, 2018

Published: August 13, 2018

Copyright ( 92018 by authors and Scientific Research Publishing Inc. This work is licensed under the Creative Commons Attribution International License (CC BY 4.0).

http://creativecommons.org/licenses/by/4.0/

\begin{abstract}
The paper chooses the listing Corporations which refinanced from June 1, 2006 to December 31, 2014 as samples to test and compare the announcement effect of five refinance modes, which are public issuance, non-public issuance, allotment and issuance of corporate bonds, and convertible bonds. Study has showed that the announcement effect of non-public issuance is positive and allotment is negative in large confidence degree, while public issuance and convertible bonds issuance show negative in a lower confidence degree, and issuance of corporate bonds isn't significant. Therefore, China's capital market favors non-public issuance most and regard convertible bonds as substitute, think allotment bearish widely, while see light issuance of corporate bonds. So, we must develop incentive effect of convertible bonds, Strengthen corporate debt's constraint mechanism, regulate the behavior of the big shareholders in allotment. It is found refinancing information leakage phenomenon in empirical research which should cause the attention of regulators.
\end{abstract}

\section{Keywords}

Listed Corporation, Refinancing, Announcement Effect, Event Study

\section{Introduction}

After the listed company announces the refinancing method and its specific financing opportunities, issue targets, prices, etc., market investors, especially the original and potential equity investors, will judge and evaluate the use of the funds for the financing, project investment, company value and future development. This reaction of investors is reflected in the acceptance of the financing, 
which is reflected in the change in the company's stock price. Therefore, listed companies must consider the possible reaction of the market when making financing decisions. Corporate financing decisions and market reactions are mutually influential and interactive. According to the theory of signal transmission theory, the choice of financing method is an important signal that the management of the company transmits the internal management and management information of the company to external investors. Therefore, the study of the market reaction after the announcement of the financing plan of listed companies provides a basis for studying the signal transmission function and the governance effect of these refinancing methods.

If the background of this research is based on a market-based investment and financing mechanism that is self-selected and self-determined, then its research conclusions will be more reliable. After a year of smooth progress in the long-term share-trading reform, it was basically completed in May 2006. At the same time, the Measures for the Administration of Securities Issuance of Listed Companies (CSRC Order No. 30, hereinafter referred to as the "Measures") were also performed in May 2006. The refinancing methods such as private placement and convertible bonds have been confirmed and regulated by the Measures. The financing methods such as public issuance, corporate bonds and share allotment have been further adjusted. The company's refinancing method is more diversified, standardized and marketization. For example, private placements no longer set a profit threshold, and convertible bonds also reduced profit conditions from $8 \%$ to $4 \%$. It can be seen that the refinancing decision of listed companies is more up to listed companies and capital markets, which provides a major opportunity for the study of refinancing signal effects.

This paper selects five kinds of direct financing methods such as the public issuance of stocks, the non-public issuance of stocks, the allotment of shares, the issuance of convertible bonds, and corporate bonds after the completion of the share reform in China and the implementation of the Measures, and studies the signal transmission effect of financing methods by observing the fluctuation of stock prices after the announcement of the plan, which will provides reliable empirical conclusions and theoretical basis for listed companies to use these financing methods to achieve effective financing and governance.

Through the research in this article, we will contribute in two aspects.

Theoretically, for the research on the market reaction of various refinancing methods, Chinese scholars are mainly based on the sample before the share reform, and mainly study the announcement effect of public issuance and non-public issuance, and there are few comparative studies in various ways. In this paper, the public issuance, non-public issuance, share allotment, issuance of convertible bonds and issuance of corporate bonds have all been studied, and they are compared and found that the private placement has been widely recognized by the market, and its AAR is positive in high confidence interval. However, allotment is exactly the opposite. The AAR trend of public issuance and 
convertible bonds is relatively consistent, and the negative effect is basically confirmed, but the significant level is not high.

In terms of empirical contribution, since Chinese scholars mainly study the announcement effect of public issuance and non-public issuance, and rarely carry out comparative research, it is difficult to provide detailed and comprehensive research on the choice of refinancing methods and the improvement suggestions of refinancing governance mechanism. This paper studies the five refinancing methods commonly used in the market, and compares and analyzes them. It can clearly see and compare the market reaction of each financing method, and can better improve the company's refinancing decision, in order to provide advice to promote better development of the company.

The structure of this paper is: the first part is the introduction; the second part is the domestic and international literature review; the third part is the event research and comparison based on the new market-oriented sample after the new regulation; the fourth part is the research conclusion.

\section{Literature Review}

Based on the consideration of financing cost and signal effect, Myers \& Majluf proposed the Pecking-order Theory, pointing out that enterprises should choose financing methods in the order of internal financing, debt financing and equity financing. Further research by scholars confirms this conclusion [1]; moreover, Asquith \& Mullins, Kalay \& Shimrat, and Brous \& Kini found that the declared effect of public offerings of new shares by listed companies is indeed negative [2] [3] [4].

However, this theory ignores the decision-making problems of various subdivision methods within the equity and debt financing methods. The research on the signal effects of these subdivision methods is left to future generations. Wruck first gave an in-depth study on the issue of private placements that existed widely in the US market. He found that the effects of private placements by US listed companies were positive, as confirmed by Hertzel \& Rees [5] [6]. However, Chen et al and Anderson et al found that the effect of private placements in listed companies in Singapore and New Zealand is negative. They believe that this is caused by the significant differences in the background of capital market institutions and regulatory rules [7] [8]. The Booth \& Smith study found that the negative effects of allotment are more serious than public issuance [9].

For the announcement effect of corporate bonds, there is a clear controversy in empirical research. Although the studies are all of the US capital market, Brounen, Arsiraphongphisit found that the company issued corporate bonds showed a significant positive effect [10] [11], Krishnaswami \& Yamanfound significant negative effects, and Ashhariet et al. found that the stock price effect is not obvious [12] [13]. The conclusions on the signal effects of the convertible bond plan announcement are also extremely different. Numerous empirical studies have shown that the issue of convertible bonds by US listed companies has a 
significant negative effect, but the effect of the convertible bonds in Japan and the Netherlands is positive. In addition, many scholars have done comparative research. Dann \& Mikkelson found that the share price effect of US convertible bonds is significantly negative, while the announcement effect of ordinary bonds is not significant [14]; Eckbo \& Masulis (1995) found that the negative effect of US convertible bonds is significant, but it is less than public issuance [15].

For the declaration effect of various refinancing methods, Chinese scholars are mainly based on the sample before the share reform, and mainly study the announcement effect of public issuance and private placement, and there are few comparative studies in various ways. As for the empirical research on the sample after the share reform, the research conclusions on the effect of share public issuance and non-public issuance are basically the same, that is, the negative effect of the former and the positive effect of the latter. For corporate bonds, Liu Qingjiang and Qi Xin, Tan Yue and Liang Xiuyan, Fu Leiming, etc. found that the share price effect of corporate bonds was not significant [16] [17] [18]. Wang Juan, and Hu Minjie et al. found that the declared effect of convertible bonds is negative [19].

There are few comparative studies on the signal effects of various financing methods after the share reform. This may be caused by the small sample size of individual financing methods. For example, the number of convertible bonds used by Fei Ming et al. is only 16 or 17 [18]. In addition, these studies directly collected samples from some databases in China, but we compared the relevant data of the current major databases, and found that they have great differences in the time and content of the same refinancing plan announcement. Obviously, this seriously affected the reliability of the study.

\section{Research Methods and Sample Selection}

\subsection{Research Methods: Event Research Method}

This paper uses the Event Study to examine the short-term response of the market to the company's refinancing announcement, that is, the signal effect of the various financing methods. The announcement date of the first announcement of the refinancing plan of the board of directors of the listed company is taken as the event day, that is, on the $0^{\text {th }}$ day. We compare and analyze the difference in signal effects between different refinancing methods by studying the difference between the actual income and the expected return of the sample company's stock during the event or event period.

\subsubsection{Estimated Expected Return (ER)}

Obviously, for the event research method, the estimate of expected return or normal return is the focus. At present, there are mainly three methods in the academic field, and the Market Model in the risk adjustment method is the most widely used. In order to facilitate the academic discussion and conclusion comparison, this paper also adopts the market model. The market model assumes 
that there is a linear relationship between the return rate of listed company stocks and a certain market return, and establishes a regression model of stock price returns based on the market returns:

$$
E R_{i t}=\alpha_{i}+\beta_{i} R_{m t}+\varepsilon_{i t}
$$

Among them, $E\left(R_{i t}\right)$ is the expected income of the sample company $\mathrm{i}$ on the $t^{\text {th }}$ day, and $R_{m t}$ is the income of the $t^{\text {th }}$ day CSI 300 index. $\alpha_{i}$ is the intercept term of the linear regression model, and $\beta_{i}$ is the slope. $\varepsilon_{i t}$ is a residual term that satisfies the research hypothesis of Fama (1968), Beja (1972), and Fama (1973), that is, the residuals between samples are independent of each other, and the mean of individual sample residuals is zero.

In this study, $(-15,15)$ is the focus of the event period; for this reason, the 184 trading days before the event period are selected as the valuation interval of $\alpha$ and $\beta$, that is, a linear relationship between actual income and market returns in $(-200,-16)$ event period is used to estimate the alpha and beta values in the regression equation.

In addition, because this study only selected Shanghai and Shenzhen stock market boards (excluding small and medium-sized board) listed companies as a sample, therefore, the Shanghai and Shenzhen 300 Index was selected as the market income. The Shanghai and Shenzhen 300 Index, selected from Shanghai and Shenzhen stock markets with high liquidity, active trading, high market value and strong representativeness, as a sample, reflects the income of mainstream investment and the overall market trend of the two cities. It is one of the most representative "barometers" in the Chinese capital market.

\subsubsection{Calculate Abnormal Return (AR)}

The abnormal return of a single stock on a certain day is calculated as follows:

$$
A R_{i t}=R_{i t}-\left(\alpha_{i}+\beta_{i} R_{m t}\right)
$$

Among them, $R_{i t}$ is the actual income of the sample company stock $\mathrm{i}$ on the $t^{\text {th }}$ day during the event period.

\subsubsection{Average Abnormal Return (AAR)}

Calculate the average value of the company's abnormal return $A R_{i t}$ for each event day, and obtain the abnormal average return $\left(A A R_{t}\right)$ of the sample's overall average for that day, i.e.

$$
A A R_{t}=\frac{1}{N} \sum_{i=1}^{N} A R_{i t}
$$

\subsubsection{Cumulative Abnormal Return (CAR)}

Calculate the sum of the abnormal average return $\left(A A R_{t}\right)$ of the sample during a certain period of the event period, and obtain the cumulative abnormal return, which represents the declared effect accumulated by the sample during the period:

$$
C A R=\sum_{t=-T}^{T} A A R_{t}
$$


If the CAR is positive, it means that the refinancing method has a positive announcement effect, while the negative is the opposite.

\subsubsection{Significant Test}

Even if the accumulated abnormal income is positive or negative, it is difficult to determine whether this declaration of refinancing exists significantly, because the stocks vary greatly and the stock market fluctuates frequently. Therefore, it is necessary to conduct a T-test on AAR and CAR. The null hypothesis $H_{0}$ is shown as follow:

$$
\begin{aligned}
& H_{0}: A A R=0 \text { or } C A R=0 \\
& H_{1}: A A R \neq 0 \text { or } C A R \neq 0
\end{aligned}
$$

If the test result rejects the null hypothesis, it indicates that there is a positive or negative announcement effect on the refinancing announcement of the listed company.

\subsection{Selection of Samples}

This study selects listed companies using the above five refinancing methods from Shanghai and Shenzhen stock market A shares (excluding small and medium-sized board) from June 2006 to December 2016 as research samples. In this study, we compare the samples of listed companies from the five refinancing methods in the three databases of CSEAN, WIND, and Hang Seng Source Database, and compare them with the announcement of listed companies one by one. We focus on the date and stock price information of the board of directors of the listed company for the first time to announce the financing plan, and further screening is performed in the following order:

- Excluding the plan for the ST and PT listed companies at the time, because the stock price of ST or PT is quite different from that of the listed companies.

- Excluding the listed companies in the financial industry, due to the nature of business operations and accounting treatment in the financial industry, which has special characteristics.

- For the sample of the board of directors that has been revised or extended several times in the refinancing decision, as long as the major issues such as the issuance method and the issuance scale are specified in the initial announcement, the first disclosure date of the round of financing will be selected as the pre-announcement date.

- Excluding listed companies that have adopted two or more refinancing methods during the event period.

- Excluding stock trading data that cannot be obtained or incomplete, and samples that have been suspended for more than 14 trading days before and after the announcement date.

After the above screening, a total of 1769 samples were obtained, and the sample sizes corresponding to each financing method are shown in Table 1. 
We make a descriptive statistical analysis of the main variables, as shown in Table 1. The results show that the mean and median of Rit and Rmt are greater than 0 , indicating that during the event period, the stock price return and market yield are positive for most of the date. The mean values of further calculated $\mathrm{AR}$ and CAR are 0.016 and 0.676 , respectively, indicating that the average rate of abnormal return and cumulative abnormal return rate of the study sample during the event window period was positive. However, the median rate of abnormal return rate was -0.195 , indicating that abnormal return of most samples are negative. In addtion, the maximum and minimum values of the abnormal return and the cumulative abnormal return indicate that some samples exhibit abnormally large or small abnormal rate of return and cumulative abnormal rate of at different event days shown in Table 2.

\section{Empirical Research}

The $\alpha$ and $\beta$ values, the market yield, and the actual yield data of individual stocks in the regression equation of this study are all from the Guotaian Database.

Using the statistical software SPSS15.0, this study obtains AAR and CAR during the event period, as shown in Table 3, Table 4, and Figure 1 and Figure 2.

Table 3 and Figure 1 show that although the corporate bond has a positive AAR during the period $(-1,0)$, the significant level is $10 \%$, and its AAR value is small during the entire period of $(-15,15)$ and there are no significant fluctuations. The AAR of convertible bonds shows a large positive change in the three trading days of the period $(-4,-2)$, and the significant level of the two trading days of -3 and -2 was $5 \%$ and $1 \%$. However, by the $1^{\text {st }}$ day before the announcement date, AAR turned down and its AAR was even as low as -1.005 on

Table 1. Sample size selected for this study.

\begin{tabular}{cc}
\hline Direct Refinancing Methods & Sample size \\
\hline Corporate bond & 465 \\
Convertible bond & 75 \\
Allotment & 92 \\
Public issuance & 106 \\
Non-public issuance & 1031 \\
Total & 1769 \\
\hline
\end{tabular}

Table 2. Descriptive statistical analysis of the main variables.

\begin{tabular}{ccccccc}
\hline stats & $\mathbf{N}$ & mean & median & sd & $\max$ & $\min$ \\
\hline Rit & 55,118 & 0.247 & 0.255 & 3.346 & 10.196 & -10.145 \\
Rmt & 55,118 & 0.092 & 0.115 & 1.817 & 9.765 & -9.24 \\
AR & 55,118 & 0.016 & -0.195 & 3.032 & 19.203 & -93.484 \\
CAR & 55,118 & 0.676 & 0.296 & 25.858 & 115.767 & -1546.82 \\
\hline
\end{tabular}


Table 3. AAR of each financing method during the event period.

\begin{tabular}{|c|c|c|c|c|c|}
\hline $\mathrm{T}$ & $\begin{array}{c}\text { Convertible } \\
\text { bond }\end{array}$ & $\begin{array}{c}\text { Public } \\
\text { issuance }\end{array}$ & $\begin{array}{l}\text { Corporate } \\
\text { bond }\end{array}$ & $\begin{array}{l}\text { Non-public } \\
\text { issuance }\end{array}$ & Allotment \\
\hline-15 & 0.206 & $-0.441^{\star}$ & -0.111 & -0.080 & $-0.570^{\star *}$ \\
\hline-14 & 0.082 & -0.067 & 0.135 & -0.075 & $-0.678^{\star *}$ \\
\hline-13 & -0.057 & -0.048 & 0.048 & 0.002 & $-0.510^{*}$ \\
\hline-12 & 0.053 & -0.058 & -0.155 & -0.003 & -0.115 \\
\hline-11 & 0.004 & -0.131 & -0.131 & 0.061 & -0.642 \\
\hline-10 & -0.164 & -0.034 & -0.029 & 0.013 & -0.090 \\
\hline-9 & -0.098 & 0.211 & -0.087 & -0.089 & 0.290 \\
\hline-8 & 0.031 & -0.171 & -0.035 & 0.044 & $-0.478^{\star}$ \\
\hline-7 & -0.086 & 0.210 & -0.036 & 0.030 & $-0.865^{* * *}$ \\
\hline-6 & -0.011 & 0.375 & -0.075 & 0.019 & -0.539 \\
\hline-5 & -0.026 & 0.237 & 0.019 & 0.052 & -0.052 \\
\hline-4 & 0.267 & $0.916^{* * *}$ & -0.164 & $0.358^{\star * *}$ & -0.171 \\
\hline-3 & $0.866^{\star \star \star}$ & -0.125 & -0.033 & $0.366^{\star * \star}$ & -0.455 \\
\hline-2 & $0.716^{* *}$ & $0.619^{* *}$ & 0.040 & $0.670^{* * *}$ & -0.169 \\
\hline-1 & -0.043 & $0.892^{\star * *}$ & $0.220^{*}$ & $1.964^{* * *}$ & -0.093 \\
\hline 0 & $-1.005^{\star * *}$ & $-0.725^{\star *}$ & $-0.278^{*}$ & $1.079^{* * *}$ & $-1.116^{\star * *}$ \\
\hline 1 & $-0.534^{\star}$ & $-0.774^{* *}$ & 0.100 & 0.055 & $-0.771^{\star *}$ \\
\hline 2 & 0.199 & 0.033 & 0.075 & $-0.232^{\star *}$ & -0.249 \\
\hline 3 & -0.150 & -0.177 & 0.116 & 0.015 & -0.269 \\
\hline 4 & -0.306 & -0.283 & -0.030 & $-0.261^{* *}$ & $-0.481^{*}$ \\
\hline 5 & -0.222 & $-0.443^{\star}$ & -0.029 & $-0.207^{\star *}$ & $-0.468^{\star}$ \\
\hline 6 & 0.131 & 0.156 & -0.039 & -0.026 & $-0.814^{* * *}$ \\
\hline 7 & 0.188 & $-0.493^{\star}$ & -0.070 & $-0.196^{*}$ & $-0.615^{\star *}$ \\
\hline 8 & 0.035 & -0.282 & $-0.159^{*}$ & $-0.176^{*}$ & $-0.533^{\star}$ \\
\hline 9 & -0.007 & -0.103 & -0.113 & 0.003 & $-0.998^{* * *}$ \\
\hline 10 & 0.414 & -0.435 & -0.056 & -0.148 & $-0.518^{\star}$ \\
\hline 11 & 0.073 & -0.350 & -0.090 & -0.092 & $-0.596^{\star *}$ \\
\hline 12 & 0.204 & -0.171 & 0.073 & -0.157 & $-0.546^{\star}$ \\
\hline 13 & 0.264 & -0.291 & 0.021 & -0.033 & $-0.477^{\star}$ \\
\hline 14 & -0.028 & -0.131 & 0.033 & -0.001 & $-0.667^{\star *}$ \\
\hline 15 & -0.104 & 0.006 & -0.181 & $-0.180^{*}$ & $-0.725^{\star * *}$ \\
\hline
\end{tabular}

Note: ${ }^{* *},{ }^{* *}$, and ${ }^{*}$ indicate significant levels at $1 \%, 5 \%$, and $10 \%$, respectively.

the announcement date and was significant at the $1 \%$ level. Finally, AAR returned to a relative stable level.

The AAR polyline of the allotment is basically below the $\mathrm{X}$-axis during the 
Table 4. CAR in several typical periods during the event period.

\begin{tabular}{cccccc}
\hline T & Convertible bond & $\begin{array}{c}\text { Public } \\
\text { issuance }\end{array}$ & $\begin{array}{c}\text { Corporate } \\
\text { bond }\end{array}$ & $\begin{array}{c}\text { Non-public } \\
\text { issuance }\end{array}$ & Allotment \\
\hline$(-15,15)$ & 0.892 & -2.057 & -1.024 & $2.774^{*}$ & $-14.980^{* * *}$ \\
$(-10,10)$ & 0.196 & -0.392 & -0.665 & $3.333^{* * *}$ & $-9.455^{* * *}$ \\
$(-5,5)$ & -0.003 & 0.002 & 0.000 & $0.051^{* * *}$ & $-0.057^{* * *}$ \\
$(-1,1)$ & $-1.582^{* * *}$ & -0.601 & 0.041 & $3.097^{* * *}$ & $-1.980^{* * *}$ \\
$(-1,0)$ & $-1.048^{* *}$ & 0.166 & -0.059 & $3.043^{* * *}$ & $-1.209^{* *}$ \\
$(-1,5)$ & $-2.061^{* * *}$ & $-1.463^{*}$ & 0.173 & $2.412^{* * *}$ & $-3.446^{* * *}$ \\
\hline
\end{tabular}

Note: ${ }^{* *},{ }^{* *}$, and ${ }^{*}$ indicate significant levels at $1 \%, 5 \%$, and $10 \%$, respectively.

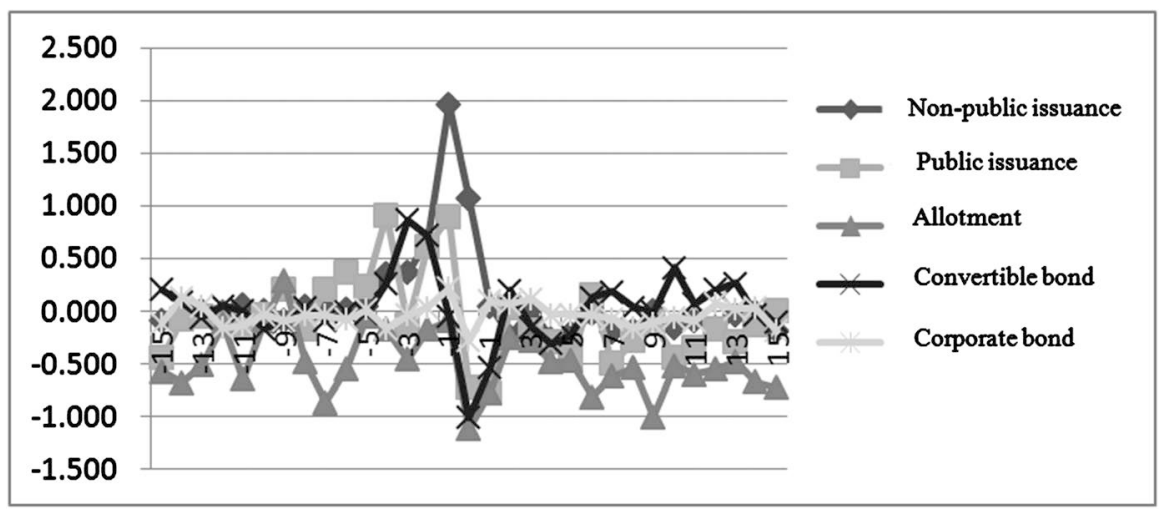

Figure 1. Comparison of AAR refinancing plans for each day during $(-15,15)$.

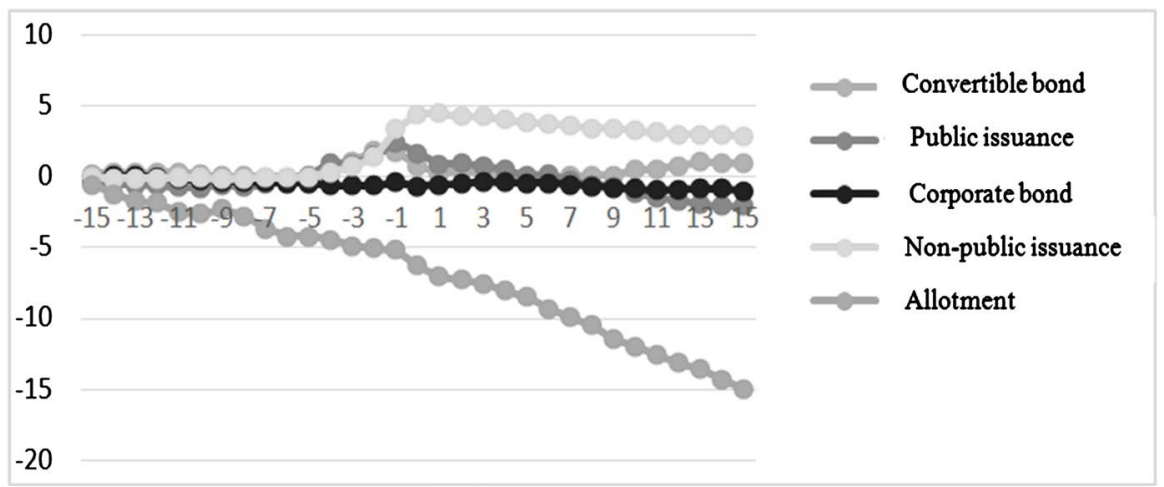

Figure 2. Comparison of CAR changes based on $-15^{\text {th }}$ day during $(-15,15)$ period.

whole $(-15,15)$ period of the event, that is to say, its AAR is basically negative, its negative effect is obvious and lasts for a long time; in addition, AAR is rapidly falling to the lowest value on the day of the announcement date, reaching -1.116 , and the level of significance is also $1 \%$. The public issuance of stocks showed a big upward break on the $4^{\text {th }}$ day, and AAR reached 0.916 , with significance at the $1 \%$ level; it experienced great fluctuation in the 5 trading days of $(-4,1)$, and the fluctuations after $1^{\text {st }}$ day are also relatively large with low confidence. However, the non-public issuance has a obvious positive effect during $(-5,1)$, while the AAR has a small range and continuous fluctuation around 0 in 
the previous $(-15,-4)$ and later $(2,15)$ periods.

In comparison, non-public issuance showed a positive return at a $99 \%$ confidence level during the $(-4,0)$ period, and the positive return were large. AAR of allotment is basically below the value of 0 during the entire $(-15,15)$ period, and the decline has increased. The AAR trend of public issuance and convertible bonds is relatively consistent, and both experienced a process of rising to positive AAR before the announcement date and then falling to a negative value. AAR of corporate bonds fluctuates around zero.

Table 4 shows the CARs for several periods of each refinancing method, and Figure 2 reflects the CARs of each day accumulated on the -5 th day basis during the period $(-5,5)$. Table 3 and Figure 2 further verify the above judgment. During the entire event period $(-15,15)$, only the cumulative negative effect of the allotment is the most convincing, and up to -14.98 ; The CAR of the non-public issuance is 2.774 , but its significance level is $10 \%$. If the accumulation period is further symmetrically contracted to $(-10,10),(-5,5)$, the cumulative effects of non-public issuance and allotment are both significant at the $1 \%$ level; if further accumulated to $(-1,1))$, then the cumulative negative effect of convertible bonds is acceptable at a significant level of $1 \%$.

\section{Conclusions}

This paper uses the event research method to study the announcement effect of several major direct refinancing methods of listed companies in China. From the process and results of the above empirical research, the non-public issuance has been widely recognized by the market, and its AAR is positive in the high confidence interval. The allotment is exactly the opposite. Moreover, the negative effect of the public issuance is confirmed, but the significant level is not high.

First, the market responded greatly during the event period, especially around the $0^{\text {th }}$ day of the event, confirming the effectiveness of China's capital market. For example, the non-public issuance, public issuance and convertible bonds have obvious fluctuations in AAR around the $0^{\text {th }}$ day of the event, which proves that the effectiveness of China's capital market is relatively high. It also shows that the event research method has market basis to study the refinancing plan announcement effect. However, there is a major suspicion of disclosure of refinancing information. For example, from $-4^{\text {th }}$ day, non-public issuance and public issuances have AARs of 0.358 and 0.916 , respectively, and the significant level is $1 \%$. Moreover, the change of positive and negative values of AAR and the occurrence of the maximum or minimum is also rarely on the $0^{\text {th }}$ day. It can be seen that strictly regulating the information disclosure of refinancing of listed companies, vigorously cracking down on insider trading, and effectively protecting the interests of small and medium shareholders are of great significance to the sustained and healthy development of China's capital market.

Second, the ability of debt financing to bind listed companies needs to be further strengthened. Among the five refinancing methods, only the AAR of cor- 
porate bonds was basically at an incredibly significant level throughout the incident study period $(-15,15)$. This shows that corporate bonds have less financial pressure on listed companies, and the company lacks the incentive to improve performance. Therefore, shareholders are not optimistic about the binding and governance role of corporate bonds on the company. This does not match the classic theory of priority financing [1]. For this reason, it is necessary to re-adjust and design the issuance clauses of corporate bonds, and enhance the governance role of debt financing on issuers with safeguarding the interests of creditors.

Third, theoretical research suggests that convertible bonds have the dual roles of "sweetened" debt financing [20] and "backdoor" equity financing [21], and the included call option can also play an incentive role. However, the empirical research at home and abroad did not reach a consistent conclusion. This study shows that the AAR announced in the convertible bond plan reached 0.866 and 0.716 on $-3^{\text {th }}$ day and $-2^{\text {th }}$ day, but reached -1.55 on the $0^{\text {th }}$ day, and the confidence level was relatively high. However, the AAR of convertible bonds is generally consistent with the public issuance. This seems to indicate that convertible bonds play a more important role in backdoor equity financing in China, and the market is not positive about it. Therefore, the convertible bond governance mechanism needs further analysis to strengthen its incentive effect on the company's management.

Finally, among the five refinancing methods, the AAR of the allotment is negative for most of the $(-15,15)$ period, and the negative value of CAR is highly reliable in many cases. "Administrative Measures on the Issuance of Securities by Listed Companies" (CSRC Order No. 30) in China stipulates that the original controlling shareholder must subscribe when the allotment is issued, but there is no provision for the issuance pricing. The domestic allotment issuance price is generally lower than the pre-release market price. This low-price issue protects the original shareholder's interests, but it may damage the company's image. It also seems to imply that the company's value is overvalued. Moreover, domestic and foreign research has also found that listed companies have the mystery of "declining performance after allotment" [22]. Therefore, China's allotment should strengthen the responsibility of the original controlling shareholder and management, and effectively protect the interests of the company and minority shareholders. The above reaction of China's capital market is in line with expectations, and it once again confirms the effectiveness of China's capital market.

In general, listed companies, investors and regulators need to develop together to maintain market stability.

For listed companies, it is necessary to arrange financing scientifically, so that the company's financing decisions will be developed in the direction of the company and investors. From the perspective of corporate governance, first of all, listed companies should improve the issuance provisions of corporate bonds, enhance the governance role of debt financing on issuers, strengthen constraints 
and improve the company's motivation to improve performance while safeguarding the interests of creditors. Second, the company should improve the governance mechanism of convertible bonds and strengthen the incentive effect of convertible bonds on the company's management. Finally, the company should strengthen the responsibility of the original controlling shareholder and management under the allotment mode to effectively protect the interests of the company and minority shareholders.

For investors, it is necessary to understand the listed companies as much as possible, make rational decisions as much as possible, and do not blindly follow.

For market supervision, first of all, it should fully consider the will of investors in the securities market when formulating relevant financing policies, and create a better policy environment for the refinancing of listed companies in order to maximize the value of financing enterprises. Second, the market supervision department needs to improve relevant laws and regulations as soon as possible to regulate the financing decisions of listed companies. Finally, the market supervision department should strictly regulate the information disclosure of listed companies' refinancing and vigorously crack down on insider trading.

\section{Fund}

2016 National Social Science Fund Project (No. 16BJY174), 2014 Humanities and Social Sciences Fund of the Ministry of Education (No. 14YJA630071).

\section{Conflicts of Interest}

The authors declare no conflicts of interest regarding the publication of this paper.

\section{References}

[1] Myers, S.C. and Majluf, N.S. (1984) Corporate Financing and Investment Decisions When Firms Have Information that Investors Do Not Have. Journal of Financial Economics, 13, 187-221. https://doi.org/10.1016/0304-405X(84)90023-0

[2] Asquith, P. and Mullins, D.W. (1986) Equity Issues and Offering Dilution. Journal of Financial Economics, 15, 61-89. https://doi.org/10.1016/0304-405X(86)90050-4

[3] Kalay, A. and Shimrat, A. (1987) Firm Value and Seasoned Equity Issues: Price Pressure, Wealth Redistribution, or Negative Information. Journal of Financial Economics, 19, 109-126. https://doi.org/10.1016/0304-405X(87)90031-6

[4] Brous, P.A. and Kini, O. (1994) The Valuation Effects of Equity Issues and the Level of Institutional Ownership: Evidence from Analysts' Earnings Forecasts. Financial Management, 23, 33-46. https://doi.org/10.2307/3666054

[5] Wruck, K.H. (1989) Equity Ownership Concentration and Firm Value: Evidence from Private Equity Financings. Journal of Financial Economics, 23, 3-28. https://doi.org/10.1016/0304-405X(89)90003-2

[6] Hertzel, M.G. and Rees, L.L. (1998) Earnings and Risk Changes around Private Placements of Equity. Journal of Accounting Auditing \& Finance, 48, 21-35. https://doi.org/10.1177/0148558X9801300102

[7] Chen, S.S., Ho, K.W., Lee, C.F., et al. (2002) Wealth Effects of Private Equity Place- 
ments: Evidence from Singapore. Financial Review, 37, 165-183. https://doi.org/10.1111/1540-6288.00010

[8] Anderson, H.D., Rose, L.C. and Cahan, S.F. (2006) Differential Shareholder Wealth and Volume Effects Surrounding Private Equity Placements in New Zealand. Pacific-Basin Finance Journal, 14, 367-394. https://doi.org/10.1016/j.pacfin.2006.01.003

[9] Booth, J.R. and Ii, R.L.S. (1986) Capital Raising, Underwriting and the Certification Hypothesis. Journal of Financial Economics, 15, 261-281.

https://doi.org/10.1016/0304-405X(86)90057-7

[10] Brounen, D. and Eichholtz, P.M.A. (2001) Capital Structure Theory: Evidence from European Property Companies' Capital Offerings. Real Estate Economics, 29, 615-632. https://doi.org/10.1111/1080-8620.00025

[11] Arsiraphongphisit, O. (2008) The Information Conveyed by Debt and Equity Announcements in Australia. International Journal of Banking \& Finance, 5, 61-86.

[12] Krishnaswami, S. and Yaman, D. (2007) Contracting Costs and the Window of Opportunity for Straight Debt Issues. Journal of Banking \& Finance, 31, 869-888. https://doi.org/10.1016/j.jbankfin.2006.06.013

[13] Ashhari, Z.M. (2009) Conventional vs Islamic Bonds Announcements: The Effects on Shareholders' Wealth. International Journal of Business \& Management, 4, 105-111.

[14] Dann, L.Y. and Mikkelson, W.H. (1984) Convertible Debt Issuance, Capital Structure Change and Financing-Related Information: Some New Evidence. Journal of Financial Economics, 13, 157-186. https://doi.org/10.1016/0304-405X(84)90022-9

[15] Eckbo, B.E. and Masulis, R.W. (1995) Seasoned Equity Offerings: A Survey. Social Science Electronic Publishing, Amsterdam, 1017-1072.

[16] Liu, Q. and Qi, X. (2009) Research on the Influence of Listed Companies' Issuance of Corporate Bonds on Stock Price. Journal of Central University of Finance and Economics, No. 9, 28-33.

[17] Tan, Y. and Liang, X. (2011) Research on the Announcement Effect of China's Corporate Bond Issuance. Accounting News. Comprehensive, No. 3, 119-121.

[18] Fu, L., Wan, D. and Zhang, Y. (2011) A New Evidence of Financing Priority Theory: A Comparative Analysis of the Declaring Effects of Corporate Debt, Convertible Bonds and Additional Stocks. Journal of Finance Review, 3, 101-114.

[19] Wang, J. and Hu, M. (2012) Analysis of Stock Price Effect of Convertible Bonds from the Perspective of Investors' Heterogeneous Beliefs. Journal of Finance and Accounting, No. 35, 8-11.

[20] Woods, D.H. and Brigham, A.E.F. (1966) Stockholder Distribution Decisions: Share Repurchases on Dividends? Journal of Financial \& Quantitative Analysis, 1, 15-26. https://doi.org/10.2307/2329883

[21] Stein, J.C. (1992) Convertible Bonds as Backdoor Equity Financing. Journal of Financial Economics, 32, 3-21. https://doi.org/10.1016/0304-405X(92)90022-P

[22] Ni, M. and Zhang, Y. (2012) Mystery of the Decline of Performance after the Allotment of Listed Companies in China-Based on the Analysis of Information Asymmetry and Principal-Agent Theory. Journal of Shanxi University of Finance and Economics, No. 10, 77-87. 